\title{
In the Presence of Absence: Commemoration and Disavowal in Congo
}

\author{
Chérie Rivers Ndaliko
}

Across the border, in Rwanda, commemoration is official. It has buildings and plaques; it has clean lines; it has dates; it has lists.

Across the border, in Rwanda, there are annual festivals, state-sanctioned repertoires. Manifestos of mourning.

Across the border, in Rwanda, commemoration is a sanctuary, a visceral transgenerational vow, an intimate and unyielding act.

I stand in solidarity with the many extraordinary Rwandese who extract from history a vigilant resilience. Daily.

But in many pockets of the world where Rwanda's story circulates beyond the stewardship of its citizens, the rigor of commemoration has been transposed. It has become the lifeblood of tourism; it has become a currency tied to the US dollar, to the great British pound, and tied, irrevocably, to the absolution of Western guilt; it has become an invocation of genocide tethered to the Holocaust as a shorthand to absolution earned not by the payment of any debt nor by any sustained act of atonement but rather by the willful addiction to African silence.

There are terms for this diagnosis. And there are heated arguments for and against its validity. The point, in my view, has less to do with who is right or wrong and more to do with what is at stake, with the reverberations that amplify or mute simultaneous truths. For this reason, I do not want to talk about Rwanda. I want to talk about what its officialdom casts into shadow. I want to talk about the mess, about the present, and about disavowal.

Critical Inquiry 44 (Summer 2018)

() 2018 by The University of Chicago. ooo93-1896/18/4404-0008\$10.00. All rights reserved.

766

This content downloaded from 152.002.176.242 on March 04, 2019 07:48:02 AM All use subject to University of Chicago Press Terms and Conditions (http://www.journals.uchicago.edu/t-and-c). 
I want to talk about Congo-where beauty, in the abstract, arises from the splatter of severed arteries-where laughter is never appropriate but never dies down. Please note: laughter is the connecting tissue for much of what I have to say about Congo. I will return, frequently, to laughter because there is no other way I can find to parse the thing that exists where commemoration ought to be. Like the art on my mind in this piece, laughter uncenters commemoration, it prods the wounds still gaping, the bodies imprisoned in a perpetual present. It is the counterpart insisting that, as memory's bedfellow, commemoration implies a past, an end, at least a pause to consider.

And for all its wealth, those are commodities Congo cannot claim.

But there is in Congo a politics of trauma. One that bleeds into art making and that will, one day, commemorate.

In the meantime, everything hinges on stories. And on laughter.

The first story:

"My childhood," she said, "is buried somewhere over there."

But now the site houses a makeshift mechanic, cobbling together communal motorbikes, readying them for the battle of lavastone streets ... that the UN promised to pave

... but never did.

"This," she says, pointing, "is preservation."

Her finality of tone precludes further questioning and I'm left to wonder whether the flippant sweep of her arm designates volcanic residue ripe for the excavation of childhood paraphernalia or teenaged grease monkeys performing denial in the face of inevitable ruin. (fig. 1)

Ruin, I extract from this exchange, is one ingredient of preservation in this place.

Another is language and the power to name; for, you see, Rwanda had a genocide, while Congo has a conflict. And conflict mobilizes forces of

Chérie Rivers Ndaliko is an assistant professor in the music department at the University of North Carolina at Chapel Hill and executive director of the Yole! Institute in the Democratic Republic of the Congo. She is author of Necessary Noise: Music, Film, and Charitable Imperialism in the East of Congo (2016) and coeditor of The Art of Emergency: Aesthetics and Aid in African Crises (forthcoming), both of which argue for critical engagement with culture in the face of active conflict. She is currently working on a multidisciplinary and multimedia project, Commemorating Congo: Unsung Stories of Resource Wars, which curates and contextualizes stories from the ongoing war in the east of Congo.

This content downloaded from 152.002.176.242 on March 04, 2019 07:48:02 AM All use subject to University of Chicago Press Terms and Conditions (http://www.journals.uchicago.edu/t-and-c). 


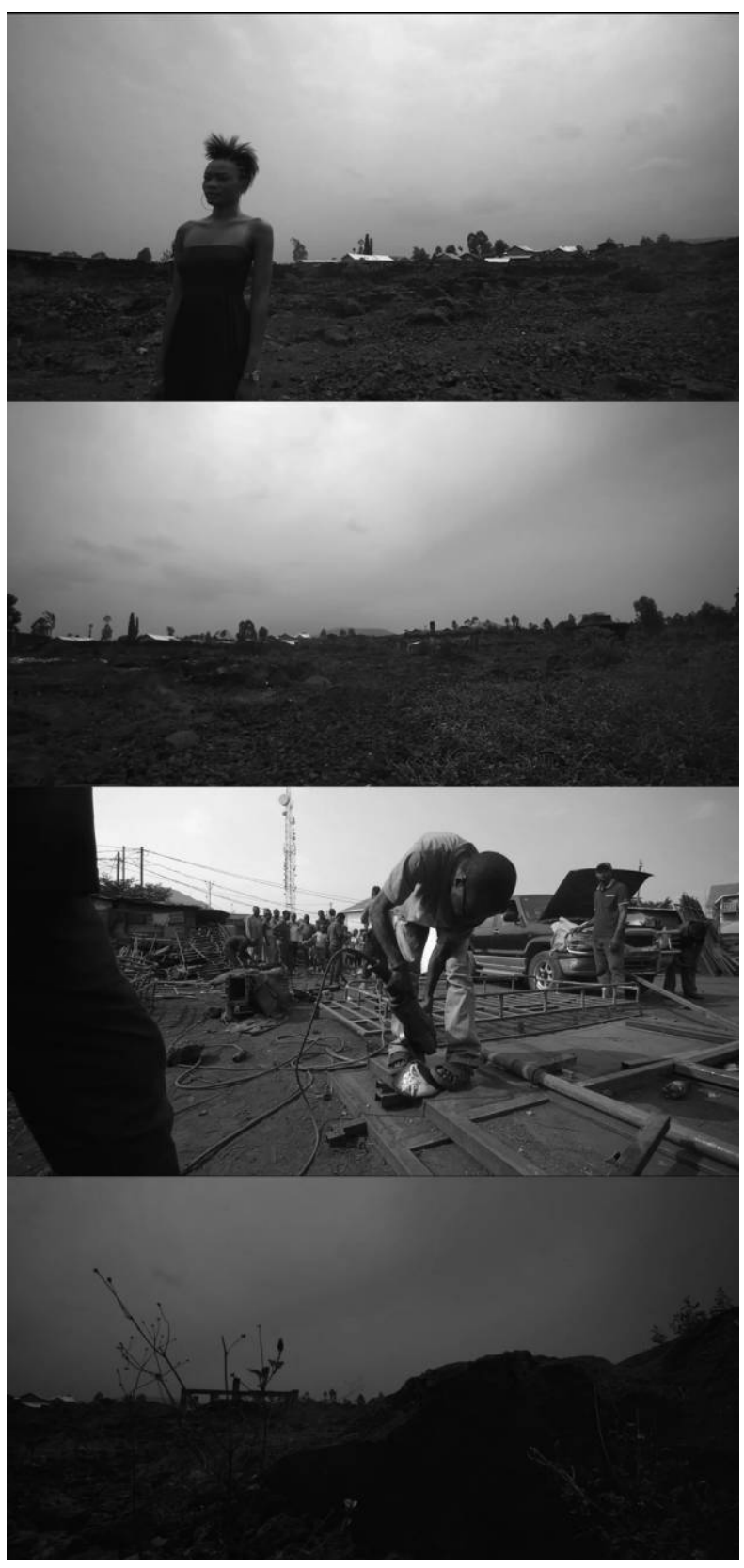

FIGURE 1

This content downloaded from 152.002.176.242 on March 04, 2019 07:48:02 AM All use subject to University of Chicago Press Terms and Conditions (http://www.journals.uchicago.edu/t-and-c). 
resolution rather than commemoration, which, in turn, coax out aspirations for the future at the expense of memories of the past. Trauma averted, history postponed, status quo cinched one notch tighter.

The second story:

I married a man from this place. He, too, has that endless laughter that accompanies stories devoid of humor.

"I lived in Holland," he once told me, "a country that has an ambulance system for pets." And he laughed. "Near a family" (and here he interrupted himself to explain to me that they were white) "a family whose children attended a school that provided post-trauma counseling for students upon the death of the aged cat adopted by the institution years back." The laughter again. "As the eldest child," he continued, "I shielded others with my body for twenty-one days as we fled through forests inhabited by militias, down paths lined with corpses on which babies still suckled, crying in fury as they failed to extract milk." More laughter, presumably triggered by his looming conclusion. "We never had post-trauma counseling," he said, "but perhaps that's because we never lost our cat."

That laughter unnerves me, mostly for what it preserves. It is a bodily act of commemoration that refuses legislation. It is a gesture, the lowest common denominator in the system of remembering on which artistic reenactments are built in the east of Congo, a place where the sum total of these illustrious notions-reenactment, commemoration, and the politics of trauma - is the stuff of bodies, whether bodies in motion or bodies prematurely stilled. It is an anatomy not writ large but writ very, very small; worn in flesh and bone, animated by raucous laughter, wielded against the tide of a floundering state that is overshadowed by the official machinery of guilt. It is the collateral damage, unintended but inevitable, in the wake of labeling genocide. Just across the border. In Rwanda.

We can - and will—scale up from here to the arts that amplify this gesture, but as you encounter them, know that laughter lurks beneath them all. The same laughter that so haunted Doris Lessing from Rhodesia through Zimbabwe; the same laughter Nancy Rose Hunt traces through time to revive imprint and echo of the human cells, the microorganisms on which statistics and truth are buoyed through time. ${ }^{1}$ In her pursuit of laughter, Hunt

1. See Doris Lessing, African Laughter: Four Visits to Zimbabwe (New York, 1992), and Nancy Rose Hunt, A Nervous State: Violence, Remedies, and Reverie in Colonial Congo (Durham, N.C., 2016).

This content downloaded from 152.002.176.242 on March 04, 2019 07:48:02 AM All use subject to University of Chicago Press Terms and Conditions (http://www.journals.uchicago.edu/t-and-c). 
draws on theory: Charles Baudelaire's "trembling laughter," George Bataille's "unknowingness" and "anguish." 2 And with theory she excavates certain remains. She diagnoses an encounter long past between a husband betrayed by his own laughter that erupted, uncouth, in his petition to recover his abducted wife. Her diagnosis: "The husband's laughter came from a realm of the immediate and visceral, the instant and direct, but its erupting sound suggests something crucial about the duration of duress." ${ }^{3}$

In the case of Congo, duress is transgenerational, its duration unimpeded by physical decline. It is its own inheritance, audible in the eruption of laughter-whether anguished, uncertain, trembling, or raucous. Yet this inheritance of sound is calibrated against very specific silences.

To get quickly to this point let me say something about assassination. For what I have to say about music and commemoration in the east of Congo, assassinations are more relevant than any abbreviated summary of the conflict, as they are an irrefutable record of silenced bodies. Unlike popular accounts of history, which are burdened with the bureaucracy of interpretation, assassinations are abrupt ruptures that render erasure visible and audible. An inheritance succinctly summarized. So let me cite these few markers before I proceed:

There was a woman, Kimpa Vita, burned at the stake for heresy. Her heresy was a plea for Congolese religious freedom.

Then there was another woman, Nyiabingi, decapitated for defiance. Her defiance was to fight for the sanctity of Congolese bodies.

Then there was a man, Patrice Lumumba, dissolved in acid for insubordination. His insubordination was to defend against the plunder of his rightful land.

Then there was another man, Laurent Kabila, shot for treason. His treason was an attempt, however righteous or reviled, to revive his nation's heroes.

Recently there was another, Mamadou Ndala, eliminated for defending hope. The hope he defended was for eventual justice.

These are but a small handful of the more notorious dreams gunned down as officialdom snuffs first the spirit, then the body, then the land,

2. Hunt, A Nervous State: Violence, Remedies, and Reverie in Colonial Congo, p. 40.

3. Ibid.

This content downloaded from 152.002.176.242 on March 04, 2019 07:48:02 AM All use subject to University of Chicago Press Terms and Conditions (http://www.journals.uchicago.edu/t-and-c). 
the memory, and eventually the faith of a people. To none of these-nor to the countless anonymous masses - is there a monument, memorial, nor any sanctioned space to commemorate.

So what is the place of music herein? To some metrics vital, to others obsolete. Both arguments rest on its perpetual work against an endlessly devolving present rather than marking a moment or mediating a receding past.

My own analysis is graphed onto axes of ruin and acceleration. Naturally, ruin is the rise, acceleration the run. Ruin is where the sedimenting layers of atrocity amass, decompose, and putrefy future possibility; where memory is overwrought by the interests of history as it conjures yet another repetition. Ruin, Ann Laura Stoler tells us, "is both the claim about the state of a thing and a process affecting it." It is, in other words, "both noun and verb." "Ruination," she continues, "is an act perpetrated, a condition to which one is subject, and a cause of loss. These three senses [act, condition, and cause] may overlap in effect, but they are not the same. Each has its own temporality. Each identifies different durations and moments of exposure to a range of violences and degradations that may be immediate or delayed, subcutaneous or visible, prolonged or instant, diffuse or direct." Finally she insists that, "ruination is more than a process that sloughs off debris as a byproduct. It is also a political project that lays waste to certain peoples, relations, and things that accumulate in specific places." 4

And I agree. In this place ruin is both noun and verb; at once a treasure trove of ideas and actions ossified into a mirror of geopolitics, failure, and counterintuitive human optimism. It is a political project that is, somewhat ironically, most evident in the failure to commemorate with the various metrics - both national and global - that mark officialdom. In this sense, there is no music, no sonic remains beyond a politically constructed silence that is, even now, laying waste to peoples, relations, and things in Congo.

That is ruin.

Acceleration, horizontal, is the ledger of ever-increasing urgency, the collective timestamps of centuries collapsing into decades that in turn cave into years, months, weeks, days, until the space between massacres is measurable in moments, in single digits of breath. Acceleration dictates - or mirrors, depending on your perspective-the soldering of violence to art and art to violence; the synchronizing of perpetration and interpretation.

4. Ann Laura Stoler, introduction to Imperial Debris: On Ruins and Ruination, ed. Stoler (Durham, N.C., 2013), p. 11. 
Acceleration is akin to rhythm, but different for its dogged lack of predictability. It is the sporadic pulse implied but not named in the frenzied denunciations that cite urgency and emergency but not cause. It is the skeleton of collective accountability, the irrevocable proof of guilt. And thus it is the target of disguise, oversimplified into a litany of facts, corralled into a timeline and condemned to stasis; it is the victim of false synonyms designed to assuage the malleable conscience of pseudoactivists who align "goodpersonness" with glory. And even that only fleetingly.

But I digress. The point is: Like ruin, acceleration is both action and thing. Thus my symbolic graph charts the songs and dances, films and videos, utterances and silences from the east of Congo onto a matrix that values output both static and dynamic. And more pressingly, it is, I hope, a barometer of irrefutable absences, an antidote to stasis, or, at the very least, a political project in its own right that aspires to help lay waste to the common practice of seeing and hearing Congo.

To this end, more stories:

A posse of eight, incumbent champions, prepared to defend their title. Lithe bodies, masters of space, with precision that casts doubt on hiphop's claims of origin. Until, the night before the finals, one member is stilled. Like that, the routine changes and so does the day. He was not a child soldier, he was a student going about his business. And now he isn't. To be sure, the new routine, rehearsed relentlessly through a sleepless night, commemorated him somehow. But none beyond the audience of that day will ever know that. It was a purging by the gasping lungs of very strong young men still caught in the fray, knowing there is more to come, that his stillness does not still the tide.

Yet to the casual viewer it is simply another routine, B-boys doing what B-boys do. (fig. 2)

There are more stories like this: lyrics recast on a moment's notice as the conflict makes itself known through the power of absence.

I remember a day, it was a beautifully blue-skyed day, an open-air concert at the foot of the volcano. Suddenly the lyrics slipped away from the group that was singing them, words morphing one by one until the momentum of musical dissent became an avalanche of accusation, the quest for catharsis mutating into an overt challenge. Because it is a war zone, there were armed soldiers passing. And because there is no sacred place 


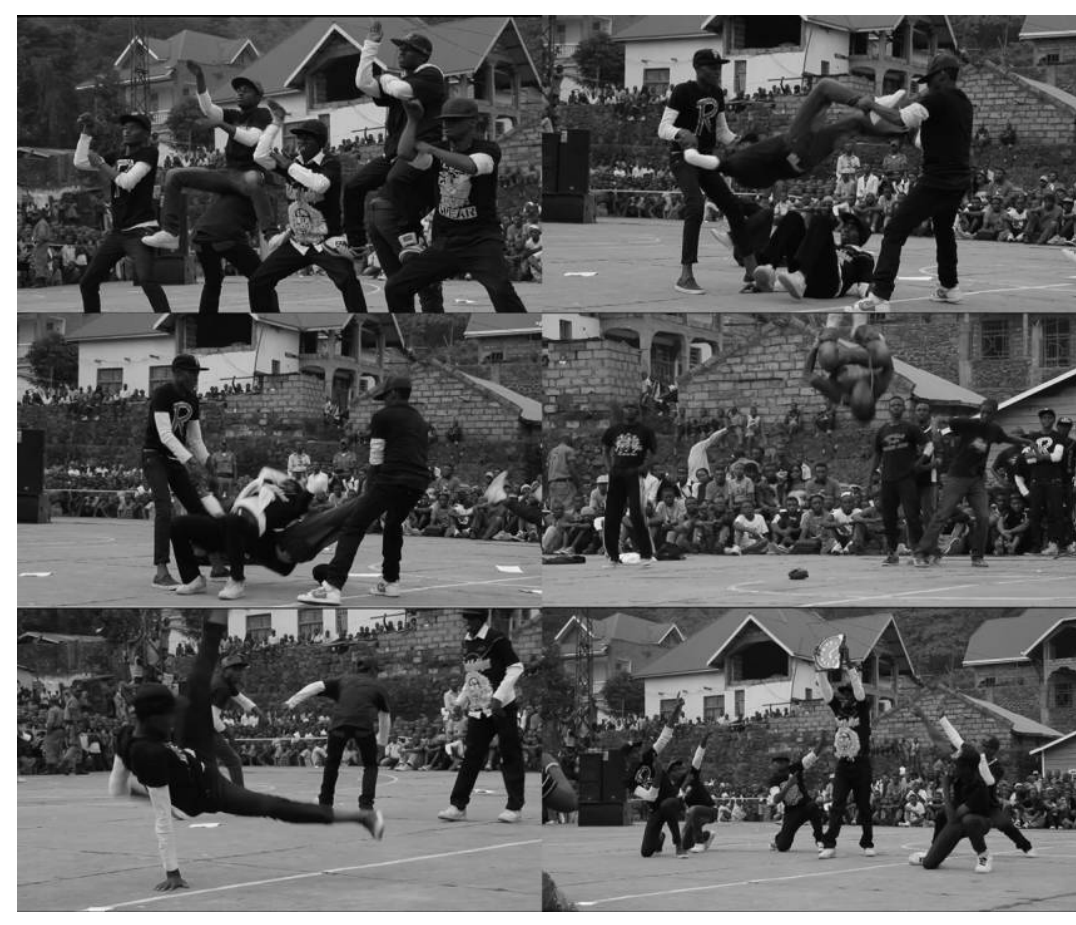

FIGURE 2 .

for grief, guilt pervades. So the soldiers took it personally-and who could blame them? But so, too, the women took it personally, for it was the demise of a beloved sister that triggered the artists' outburst. Suffice it to say, things escalated. Accelerated. And ruined. (fig. 3)

The residue, visceral but otherwise erased, yielded a lesson: in the absence of officialdom, commemoration is the shared gasp, the synchronicity of breath, the reflex to resist the exhale, the centrifugal force of fragmented memory that brings fearful bodies into instant unison.

But listening that day-and many times since-to the song itself, I am struck by this: In these beats, this flow, the hooded scowl and hoodlum bounce of bodies sporting the spoils of an indecipherable capitalism, there is nothing particularly Congolese, nothing that insists that this song is for these people in this place, the only place where this particular history is taking these particular lives. No, these examples are subcutaneous. And thus they recede. Leaving, if anything, a residue obscured by the global sprawl 


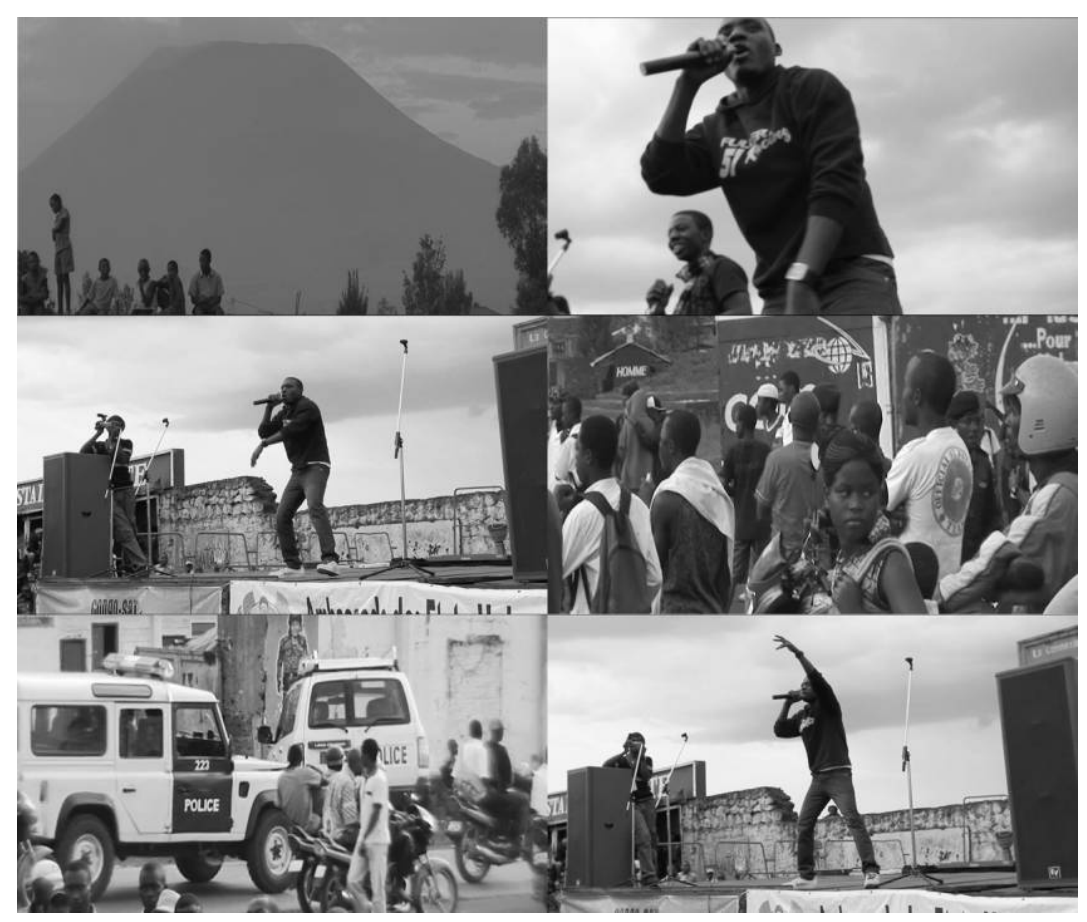

FIGURE 3 .

of consumer culture where fragmentation and the mercenary repurposing of beats does not decry the ruination of Congo's unique collision with geopolitics, but rather the summary diminution of attention span characterizing the spawn of the digital age. Commemoration subsumed by its mode of delivery, by grand ideas of borrowings, cultural retention, by an aesthetic that performs belonging to a global South where blackness is the currency, assault the assumption. Specific histories blurred by collective subordination.

And like that, shared disenfranchisement replaces specificity and their art shifts the one-degree separating commemoration from protest for so many black bodies. This is one sleight of hand stifling the performance of commemoration in the east of Congo, eviscerating reenactments of atrocity with vague yet equally political alliances that imply, but do not state outright, that history is secondary to assault.

My take is that history, like the present, is assault. Thus risk does not impede art nor preservation motivate it. That is what I hear in the lyrics citing the putrid accumulation of failed promises by a disempowered state; that is 
what I read between the lines of pitch, volume, and distortion that assail the eardrums of anyone-willing listener or otherwise-within range; that is what I see in the relentless, punishing acrobatics that catapult unarmed bodies into the air despite the cratered tarmac, the burning heat, the inevitability of gravity.

On that beautifully blue-skyed day at the foot of the volcano the words themselves were simple:

Walisema watajenga, watajenga balabala

Walisema watajenga, watajenga hospitali

Walisema watajenga, watajenga byamaana

Walijenga?

Hapana!

Walijenga?

Hapana!

. . .

Wabakaji wale, wabakaji wale

Police!

Munzenze wote, munzenze wote!

. . .

Walisema watajenga, watajenga balabala

Walisema watajenga, watajenga hospitali

Walisema watajenga, watajenga byamaana

Walijenga?

Hapana!

Walijenga?
They promised to build roads

They promised to build hospitals

They promised to build meaningful things

Did they build them?

No!

Did they build them?

No!

$\cdots$

Here are the rapists

Police!

Take all of them to central prison!

. .

They promised to build roads

They promised to build hospitals

They promised to build meaningful things

Did they build them?

No!

Did they build them? 
Indeed, the words are simple. But the story they tell is not. The pronouns ambiguous, the tense equally so; gestures fill in for precision; interpretation becomes a matter of urgency; and unvoiced questions abound- "the rapists?" "where?" "the police?" "take whom to prison?" "the police?" "did you hear about X? they must be talking of her" ("tragedy! now what will her children do?") "and in her case it was the police?" "what police?" "those police there?" So unfurl the simultaneous afterlives of lyrics. Perhaps that is why they slipped away from the group that was singing them.

Is this commemoration?

To my mind the jury is still out. And that is as much a temporal question as an aesthetic one. For nothing I have mentioned ends where I have left it. None of this ends at all. Not with my meager list of assassinations, not with my paltry roster of anonymous erasures, not with sweeping gestures laying the spoils of history at Léopold's feet. It. Does. Not. End. And so it is not commemorated, not reenacted but rather mirrored, shadowed, absorbed by bodies and spat back out in lyrics and choreographies that, like their progenitors, remain unpreserved.

That is the politics of trauma in this place. I am leaning toward translation as my term of choice. Under these circumstances of constancy the best art can hope for is to translate. Reenactment is a luxury too closely associated with if not the end of, at least distance from, perpetration; translation, on the other hand, is a mode of survival, a means of purging shock from gasping lungs, a reflex conditioned by the matrix of ruin and acceleration.

Translation, it seems to me, is a means of patrolling the intersection of memory and musculature, of performing, even if only for the wind, a primal assertion of being, and being human, despite the odds, of marshaling ephemera into a counternarrative that says, "We are here. Or at least we were."

And translation in the east of Congo happens in real time. When Mamadou Ndala was assassinated, his story became-within momentsthe raw material of choreographies that translated his demise, parodying the margins between the embodied disciplines of drill and dance, stylizing the synchronicity of combat with the flair of crunk, erupting with the acrobatics of war and art. In his honor, soldier-dancers performed (for the audience of a local arts festival) the literal routines of military life-basic training in makeshift barracks, authoritarian demonstrations of patriotism, the inevitable brutality of ambush, massacre, and the harvesting of bodies by a beleaguered army of Red Cross workers. At the same time, and with equally military precision, these dancer-soldiers coopted gestures of allegiance to nation to pledge allegiance to their craft-punctuating the rituals of vio- 
lence with fleeting displays of coetaneous grace, corralling their limbs into an homage to the many-armed gods who destroy and create with equal conviction (fig. 4).

Mamadou Ndala's story was the heart of this routine to be sure, and yet his demise was only a preface to the acrobatic feats yet to come. This piece, never named, was not a reenactment of a past however recent but a translation by living bodies of the daily perils to which no one is immune. It was, perhaps, a fleeting tribute, a staid nod in recognition of an abrupt ending, but one rooted in firm denial of any possibility of leaving a tangible trace. Thus it commented doubly on trauma without commemoration, as a reminder of what will not be remembered but will rather congeal into another thin crust in the sedimenting layers of ruin. And the pace of its recession into the devolving present is, for anyone paying close enough attention, a signal that acceleration is a permanent temporality of duress in the absence of sanctioned memorial.

Perhaps that is why this piece elicited such robust laughter from the crowd of thousands who attended, by happenstance, its one and only staging.

For laughter is not only "trembling," "unknown," or "anguished," it is also a metric of the many things that get lost in translation. And while its erupting sound suggests something crucial about the duration of duress, it also suggests something about the ability to see beauty despite the odds; the ability to translate, from chaos, the energies of creativity; the ability to mine the intersection of memory and musculature for traces of imagination that affirm - at least for a moment-that being here is more than happenstance. Such laughter prods the wounds still gaping and extracts from bodies imprisoned in this perpetual present a pause to consider.

Thus laughter, like the music and dance entangled with it, and indeed like this very essay itself, is a micropolitical gesture that charts a course between omnipotence and impotence. Like ruin, it is a product and a process, an act, condition, and cause that animates and renders palpable the presence of absence.

I have passed through Rwanda many times without hearing such laughter. That, too, is an echo of officialdom.

And that seems to me to be one crux of this very awkward matter-that commemoration calibrated to a real or imagined West suffocates African laughter along with African lives. That is not to say I have an alternative; I most certainly do not. What I do have is an arsenal of stories and a political 


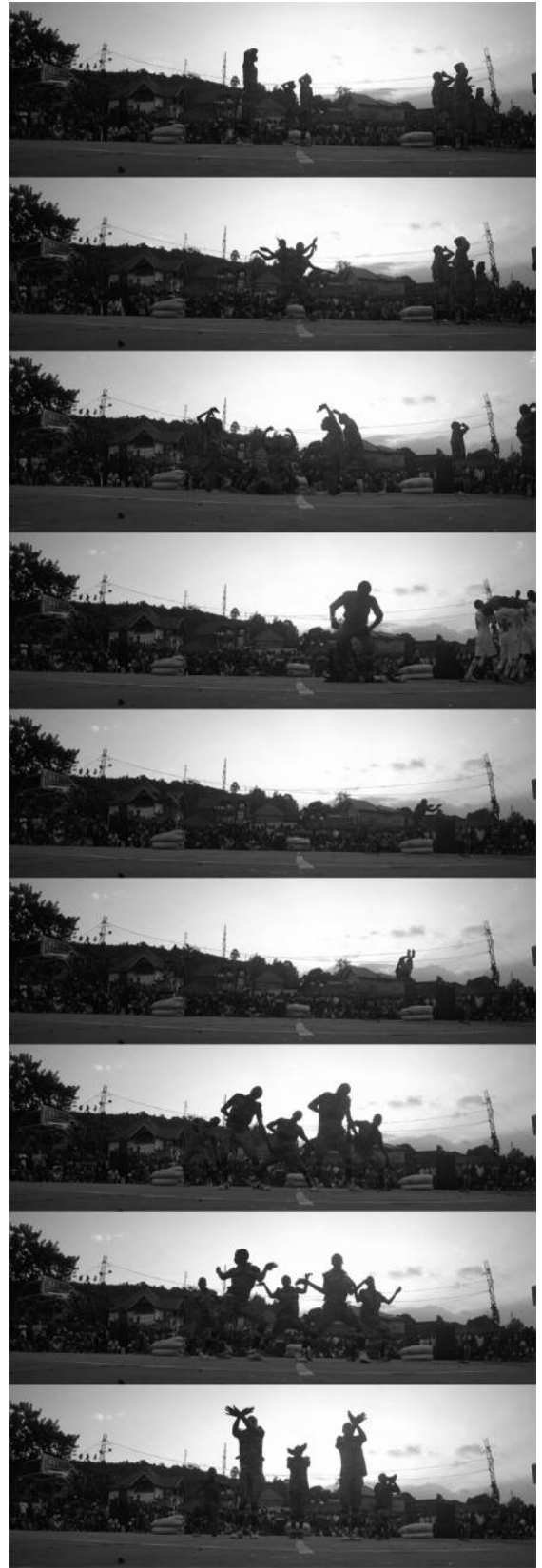

FIGURE 4 . 
commitment to bearing witness, to harvesting from the perpetual present traces of memory that can, in turn, be reinscribed in the political project of breaking the willful addiction to African silence with reminders of the pulsing bodies and raucous voices that even now proclaim their stories (fig. 5). Just across the border. In the Congo.

This content downloaded from 152.002.176.242 on March 04, 2019 07:48:02 AM All use subject to University of Chicago Press Terms and Conditions (http://www.journals.uchicago.edu/t-and-c). 


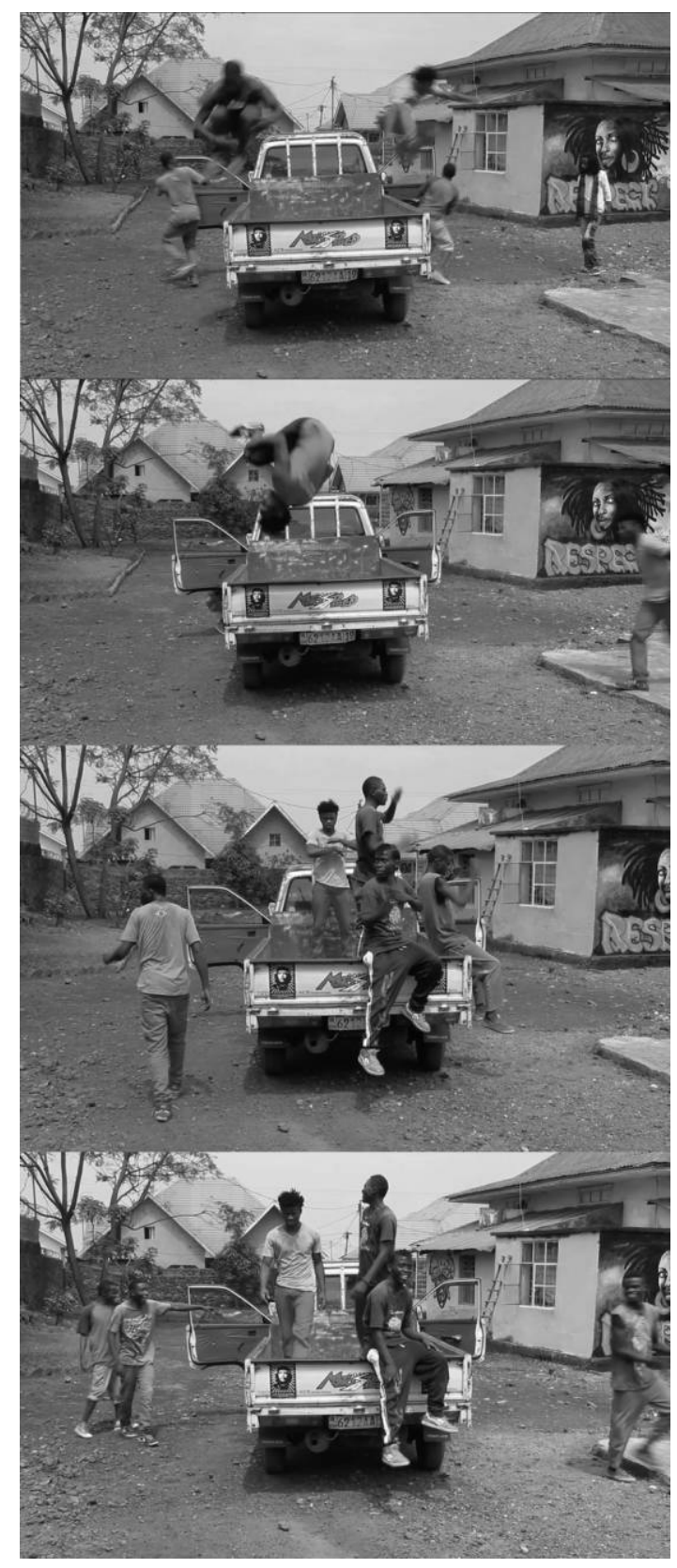

FIGURE 5

This content downloaded from 152.002.176.242 on March 04, 2019 07:48:02 AM All use subject to University of Chicago Press Terms and Conditions (http://www.journals.uchicago.edu/t-and-c). 